\title{
Diversity and life-history traits of wild bees (Insecta: Hymenoptera) in intensive agricultural landscapes in the Rolling Pampa, Argentina
}

\author{
Violette Le Féon ${ }^{\mathrm{a}, \mathrm{b}}$, Santiago L. Poggio ${ }^{\mathrm{a},}$, Juan Pablo Torretta ${ }^{\mathrm{d}}$, Colette Bertrand ${ }^{\mathrm{e}}$, \\ Gonzalo A. R. Molina ${ }^{a, f}$, Françoise Burel ${ }^{g}$, Jacques Baudry and Claudio M. Ghersa ${ }^{a, f}$
}

aIFEVA/Facultad de Agronomía, Universidad de Buenos Aires/CONICET, Buenos Aires, Argentina; 'bINRA, UR 406 Abeilles et Environnement, Avignon, France; 'Cátedra de Producción Vegetal, Facultad de Agronomía, Universidad de Buenos Aires, Buenos Aires, Argentina; 'CONICET/Cátedra de Botánica General, Facultad de Agronomía, Universidad de Buenos Aires, Buenos Aires, Argentina; eINRA, UR 980 SAD-Paysage, Rennes, France; 'Cátedra de Ecología, Facultad de Agronomía, Universidad de Buenos Aires, Buenos Aires, Argentina; ${ }^{9}$ CNRS-UMR Ecobio 6553, Centre Armoricain de Recherches en Environnement, Université de Rennes 1, Rennes, France

\begin{abstract}
The decline of bees is a major concern due to their vital role in pollinating many crops and wild plants. Some regions in South America, and especially the Pampas, are amongst those parts of the world where stressors of bee populations have been little studied. The Pampas has been intensively transformed for agriculture, being presently one of the most productive areas of agricultural commodities in the world. Here, we aim to provide first insights on the taxonomic and functional composition of bee assemblages in the Rolling Pampa, the most intensively managed part of the Pampas. Soybean (herbicide-tolerant genetically modified varieties) is the predominant crop in this region. Bees were sampled with coloured pan traps. Sampling points were located on field margins in either the cropped or the semi-natural grassland area of a farmland site devoted to annual cropping. A total of 2384 individuals were caught, representing 33 taxa [mainly (morpho)species]. The subgenus Lasioglossum (Dialictus) largely dominated captures (78\% of the total abundance) and was relatively abundant in the entire study area, suggesting that some species are likely to reach their ecological requirements in cropped areas. No-till fields and field margins may provide large areas for these below-ground nesting species, while their polylectic food preferences allow them to collect pollen on a wide range of plant species, among them possibly soybean. On the contrary, the richness and the abundance of other taxa were higher in the seminatural area than in the cropped area. Among them, aboveground nesting or oil-collecting species, which have more specialised nesting and floral requirements, were highly associated with the semi-natural area. Our findings highlight the large dominance of $L$. (Dialictus) species in this highly intensively managed landscape, and the urgent need of preserving semi-natural habitats to maintain species-rich and functionally diverse bee communities in the Pampas.
\end{abstract}

\section{ARTICLE HISTORY}

Received 13 August 2014

Accepted 23 October 2015

Online 16 December 2015

\section{KEYWORDS}

Functional diversity; herbicide-tolerant genetically modified soybean; Lasioglossum (Dialictus); no-tillage; wild bees 


\section{Introduction}

Since bees are recognised as the most important group of pollinators worldwide (Michener 2007), their decline has become of major concern (Steffan-Dewenter et al. 2005; Biesmeijer et al. 2006; Potts et al. 2010). A growing literature has emerged dealing with drivers of bee decline (Ricketts et al. 2008; Brown and Paxton 2009; Winfree et al. 2009; Potts et al. 2010; Vanbergen and The Insect Pollinators Initiative 2013; Goulson et al. 2015). As described in a recent review (Goulson et al. 2015), this decline is due to multiple, interacting factors such as habitat loss, pesticides, climate change, parasites and diseases. Among them, habitat loss associated to urbanisation and the conversion of natural and semi-natural habitat to farmland have been long-term negative factors (Goulson et al. 2015). However, most of the studies have been conducted in Europe and North America, while important, biodiversity-rich regions are poorly investigated (Archer et al. 2014).

South America is one of those parts of the world where stressors of bee populations have been less studied than in Europe or North America. Moreover, in countries where bee surveys have been conducted, including Argentina, Brazil and Colombia, studies tend to be restricted to few regions, leaving many others unexplored (Freitas et al. 2009). The Pampas, a vast grassland region in eastern central Argentina, Uruguay and southern Brazil (Soriano 1991), is among the regions where bee ecology has been little studied, though research on this group has increased during the last decade (Torretta et al. 2010; Medan et al. 2011; Sáez et al. 2012; Torretta and Poggio 2013; Marrero et al. 2014). However, as far as we know, bee assemblage composition has not been previously assessed in the Rolling Pampa, the most intensively farmed region in the Pampas.

To persist in a landscape, populations of wild bees require suitable nesting sites as well as floral nectar and pollen as food resources for both adults and larvae, and these resources must occur within the flight range of the species (Westrich 1996). The Rolling Pampa has been dramatically homogenised due to agricultural intensification, particularly since the rapid adoption of both no-tillage and herbicide-tolerant genetically modified (HTGM) soybean [Glycine max (L.) Merr.] varieties in the 1990s (Baudry et al. 2010). Regarding habitat quality for bees, farmland in this region is characterised by the low proportion of semi-natural habitats in the landscape, and the scarcity of nectar and pollen resources. However, Pampean soils have a low disturbance due to the widespread use of no-tillage. No-tillage makes soils practically undisturbed in comparison to regularly ploughed fields. No-till soils are therefore potentially more suitable for bees nesting below ground. In contrast, the low availability of semi-natural habitats can limit the presence of above-ground nesting species, which require various types of micro-habitats and pre-existing cavities to establish their nests (e.g. Sheffield et al. 2008; Kremen and M'Gonigle 2015).

In the Rolling Pampa, wild flowers are mostly associated with non-cropped habitats, such as fragments of semi-natural vegetation in grasslands and along field margins and roadside verges. These habitats are usually affected by herbicides, which can result from either drift during applications in adjacent fields or direct applications to control the vegetation in field margins and roadsides (Poggio et al. 2010). Moreover, widespread growing of soybean has promoted the opportunistic cultivation of road verges, and the removal of fencerows to enlarge fields. Flowering crops can provide abundant food resources for bees (Westphal et al. 2003; Requier et al. 2015). In the Rolling Pampa, 
prevalent crops, maize (Zea mays L.) and soybean, even if they are not considered highly rewarding crops such as oilseed rape (Brassica napus L.) and sunflower (Helianthus annuus L.), could be a source of pollen (maize and soybean) and nectar (soybean only). Albeit little is known about soybean visitor-insects (Chacoff et al. 2010; Garibaldi et al. 2011a), it has been observed that some wild bee species visit soybean inflorescences (Rust et al. 1980; Milfont et al. 2013; Monasterolo et al. 2015). The use of pollen of maize has been recorded in the honeybee (Apis mellifera L.: Apidae), but to our knowledge no such observation has been reported for wild bee species.

Our objective was to provide a first characterisation of wild bee assemblages occurring in the Rolling Pampa and to assess the affinity of bee species to cropped versus semi-natural areas in this intensively managed region. Our research provides novel information from several perspectives. First, bee assemblages have not been previously assessed in this region. Second, bees have been rarely studied in large areas devoted to growing HTGM soybean under continuous no-tillage management, despite the large development of this farming system in the last few decades worldwide (Milfont et al. 2013). Finally, bee species were also characterised according to life-history traits. Considering life-history traits concurrently with taxonomic composition contributes to identifying more general patterns of bee responses to environmental disturbances (Moretti et al. 2009; Williams et al. 2010; Sheffield et al. 2013a).

\section{Materials and methods}

\section{Study area}

The study was carried out in the central Rolling Pampa in Argentina (Figure 1a, b). Climate is temperate and sub-humid, with hot summers and no marked dry season (Burgos and Vidal 1951). Annual average rainfall is about $1000 \mathrm{~mm}$ and annual average temperature is $17^{\circ} \mathrm{C}$ (Hall et al. 1992). Topography is gently undulating and crossed by streams.

Soybean is the prevalent warm-season crop (sown in early November), grown in about $75 \%$ of the cropping area, followed by maize, grown in about $20 \%$ of the cropping area (DPEBA 2011). Maize has been rapidly displaced by soybean since the inception of HTGM varieties in 1996. Soybean is also sown as a double crop immediately after the harvest of winter crops - mostly wheat, which is the widespread cool-season crop in the region. Nearly all soybean fields are sown with HTGM varieties. No-tillage is the widespread practice to sow row crops. Landscapes are coarse grained, with large, square fields (mean field area \pm standard error $(\mathrm{SE})=62 \pm 2.8 \mathrm{ha}$ ), which are bounded by wire fences. Besides soybean, pollinator-dependent crops grown in the Rolling Pampa are oilseed rape, sunflower and alfalfa (Medicago sativa L.), all present in a very small part of the cropping area (less than $2 \%$ of the area each).

Bee surveys were carried out in a farm (Estancia 'Las Polvaredas', partido de Rojas, provincia de Buenos Aires, $34^{\circ} 07^{\prime} \mathrm{S}, 60^{\circ} 34^{\prime} \mathrm{W}$ ) comprising about 4400 ha of croplands and grasslands. A narrow stream (Arroyo Dulce) divides the farm into two groups of fields located on both sides (Figure 1c). Fields along the stream are occupied by semi-natural grasslands (about $10 \%$ of the total area), hereafter referred as 'semi-natural area' (Figure 2a, b), whereas the remaining fields are devoted to annual crops (soybean, maize and, to a lesser extent, wheat), hereafter referred as 'cropped area' (Figure 3). 


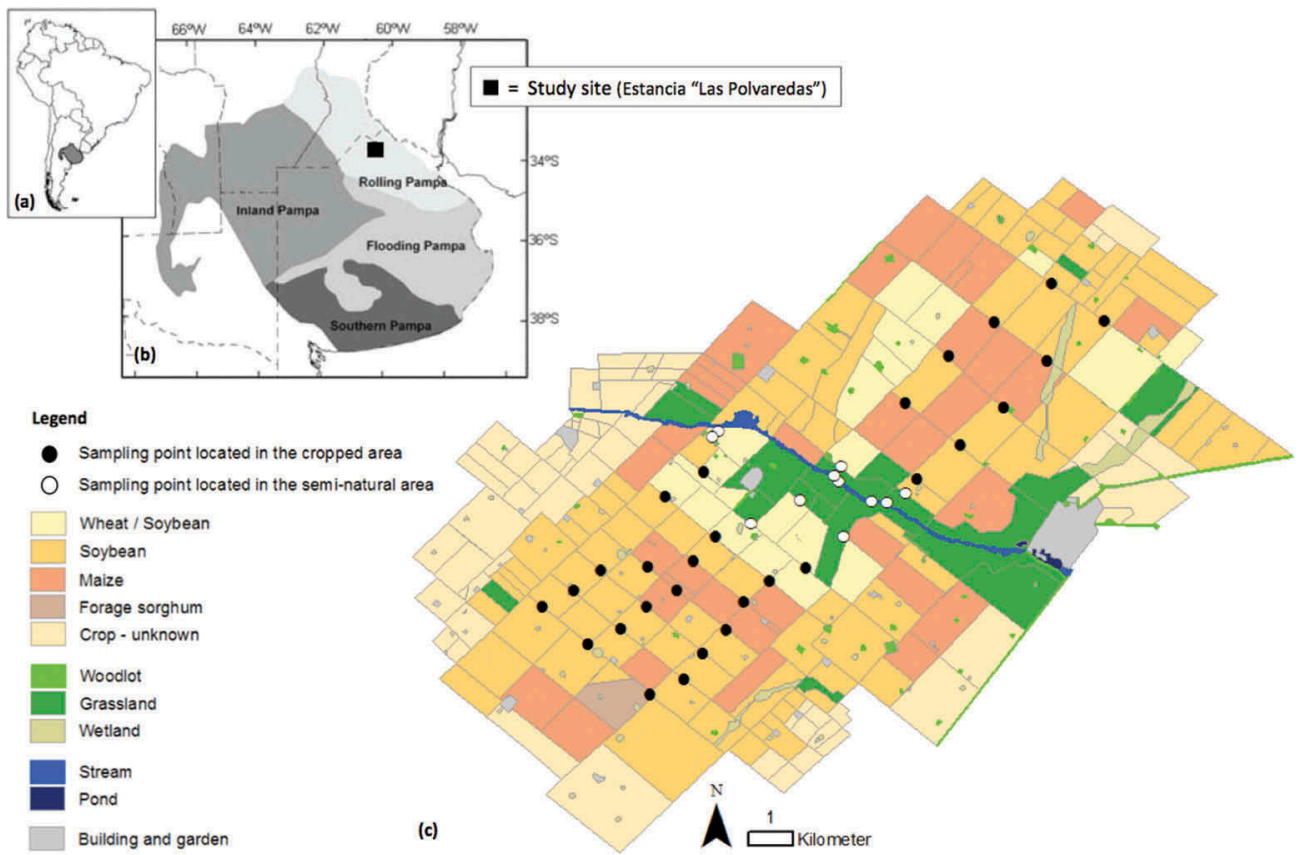

Figure 1. Location of (a) the Argentinean Pampas in South America, (b) the study site (Estancia 'Las Polvaredas', partido de Rojas, provincia de Buenos Aires; black square) in the Rolling Pampa and (c) the 39 sampling points in the study site. The map shows the land use of the year when bee sampling occurred (2010-2011 growing season). Black dots represent points located in the cropped area $(n=28)$, and white dots represent points located in the semi-natural area $(n=11)$. On each point, bees were collected with pan traps (one blue, one white and one yellow) during three 48hour sessions.

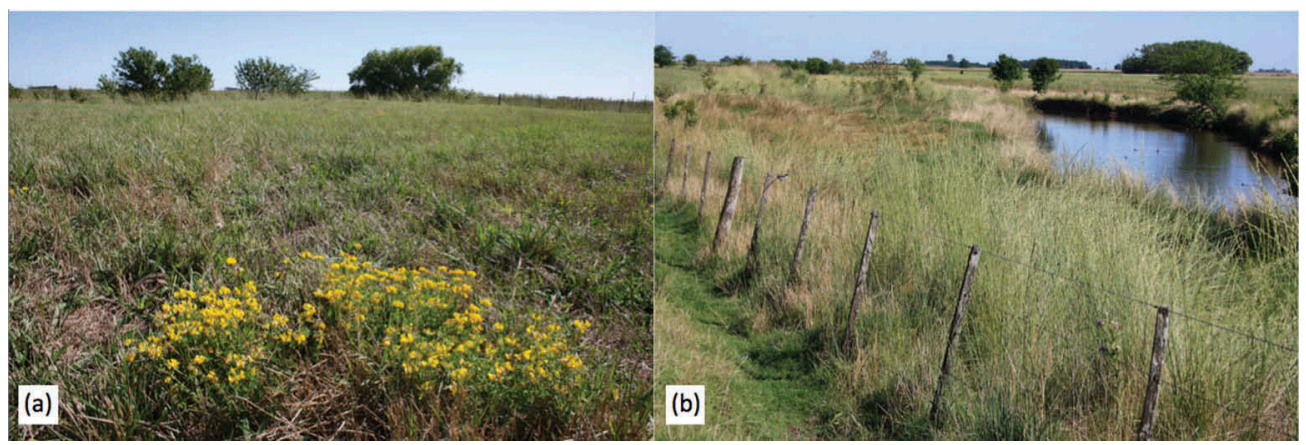

Figure 2. Semi-natural area of the study site: (a) semi-natural grassland; (b) the stream 'Arroyo Dulce' and its banks (Photos: Violette Le Féon).

In our study site, field margin vegetation is mostly herbaceous, and some woody plants, such as small shrubs, were only occasionally present. A plant survey carried out during the same period (see Molina et al. 2014) found that the common flowering plants along fencerows and crop edges were Amaranthus hybridus L. and Chenopodium album L. (Amaranthaceae), Bidens subalternans (L.) Schltdl., Carduus acanthoides L., and Conyza 


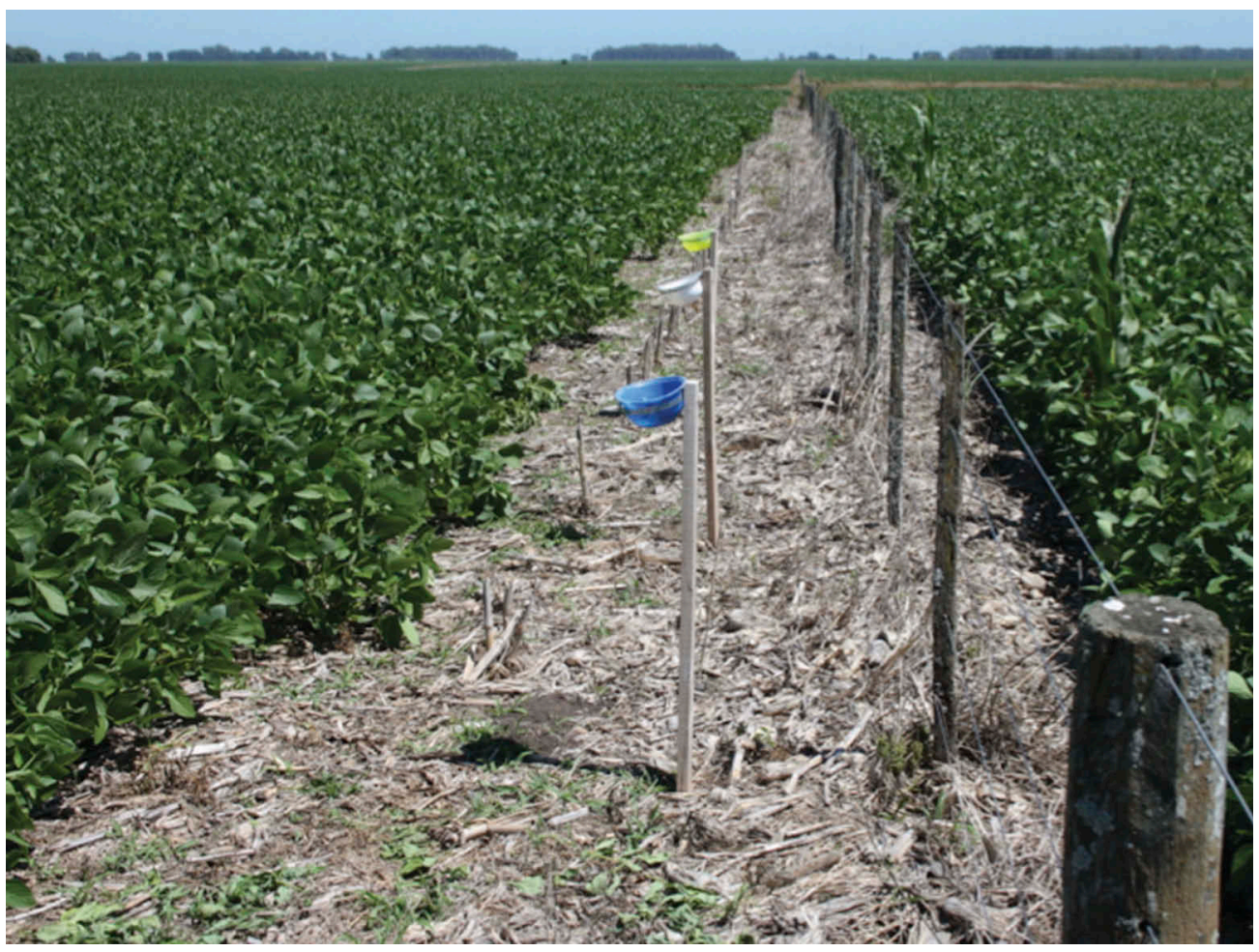

Figure 3. A representative sampling point in the study site, which shows three pan traps deployed in line near a wire-fence row delimiting two soybean fields (Photo: Violette Le Féon).

bonariensis (L.) Cronquist (Asteraceae), and Anoda cristata L. (Malvaceae), all having relatively low cover (Molina et al. 2014). Common grasses (Poaceae) were Digitaria sanguinalis (L.) Scopoli and Sorghum halepense (L.) Pers. Small homesteads and woodlots are scattered over the landscape, which cover between 0.5 and 2 ha. Woodlots are composed of non-native tree species (Fabaceae: Robinia pseudoacacia L., Meliaceae: Melia azedarach L., Moraceae: Broussonetia papyrifera (L.) Vent., Morus alba L., Myrtaceae: Eucalyptus spp., Oleaceae: Fraxinus americana L., Ligustrum lucidum W.T. Aiton, Salicaceae: Populus spp. L.).

Our study site is representative of intensively managed farms in the central Rolling Pampa regarding landscape structure, grown crops and the composition of plant species assemblages (Poggio et al. 2013; Molina et al. 2014). Regarding the presence of grasslands, the situation may differ. Grasslands are still present in our site, occupying the banks of the central narrow stream. But in many farms of the Rolling Pampa, most fields have been converted to continuous annual cropping.

\section{Bee sampling}

Bee sampling was done using coloured pan traps in three periods: late spring (13-15 December 2010), mid-summer (20-22 January 2011), and late summer (1-3 March 2011). Pan trapping has been shown to be the most efficient method for sampling bees, 
especially for assessing the overall species richness of a study site (Westphal et al. 2008). We also chose this method with regard to the scarcity of wild flowers in our study area and the induced difficulty in detecting bees (Cane et al. 2000). We were conscious of the potential biases of this method that can underestimate some bee groups, like Colletes (Colletidae) and large bees such as Bombus (Apidae) (Roulston et al. 2007; Westphal et al. 2008). However, it is worth noting that bees from the genus Bombus were found to be scarce in a netting survey carried out in several sites in the Pampas (Marrero et al. 2014).

Traps consisted of 500-mL plastic bowls that were sprayed inside with an ultraviolet (UV)-reflecting paint (Rust-Oleum Corporation, USA; brilliant blue, reference 262156; brilliant white, reference 262098; brilliant yellow, reference 262158). Each bowl was mounted on a wooden pole at $1 \mathrm{~m}$ height and filled with $400 \mathrm{~mL}$ of water with a drop of detergent. A total of 39 sampling points were regularly distributed throughout the farm (Figure 1c). Eleven points were located in the central semi-natural and 28 in the cropped area. At each sampling point, a set of three pan traps of different colours was installed at the field edge nearby fences (Figure 3). The three traps were placed linearly in random order $2 \mathrm{~m}$ apart and were deployed continuously during 48 hours under suitable diurnal weather conditions for bee activity (Leong and Thorp 1999; Westphal et al. 2008). To reduce collection biases, the installation order of the three colours was rotated between sampling rounds. Bowls were emptied at the end of each sampling day and bees were stored in $70 \%$ ethanol.

Non-bee insects and other arthropods sampled were not examined further. These included many Coleoptera [Astylus atromaculatus Blanchard (Melyridae) and Cyclocephala signaticollis Burmeister (Scarabaeidae) were the two most abundant species] and a few Diptera (including some Syrphidae), Lepidoptera and arachnids, among others. Fourteen individuals of honeybee were also caught, which were excluded from data analyses because our study focused on wild species. Bees were identified in the laboratory to the finest taxonomic level possible. Taxonomy followed the nomenclature of Michener (2007). Due to the lack of an identification key, individuals from the genus Lasioglossum subgenus Dialictus (Halictidae) could not be identified to the species level. All bee specimens are preserved for future reference in the entomological collection of the General Botany Unit, at the School of Agriculture, University of Buenos Aires.

\section{Life-history traits}

Bee taxa were described according to five life-history traits, which have been shown to be important in bee auto-ecology and to determine the response of bees to environmental disturbance (Moretti et al. 2009; Williams et al. 2010; Sheffield et al. 2013a; Kremen and M'Gonigle 2015): body size, reproductive strategy, sociality, nest location and trophic specialisation (Table 1). Body size was obtained from the examination of our specimens. For the other traits, information was compiled from the primary literature (Michener 2007) and specialised publications (Martins and Borges 1999; Cocucci et al. 2000; Aguiar and Melo 2009; Torretta et al. 2010, 2012; Dalmazzo and Roig-Alsina 2012, 2015). Regarding trophic specialisation, we distinguished between polylectic species collecting pollen on several plant families and specialist oligolectic species collecting pollen on a single plant family. We also checked which species were oil-collecting bees, 
Table 1. Life-history traits used to characterise bee taxa (derived from Williams et al. 2010).

\begin{tabular}{|c|c|c|}
\hline Trait & Categories & Definition \\
\hline Body size (total body length) & $\begin{array}{l}\text { Small } \\
\text { Medium } \\
\text { Large }\end{array}$ & $\begin{array}{l}<7 \mathrm{~mm} \\
7-14 \mathrm{~mm} \\
>14 \mathrm{~mm}\end{array}$ \\
\hline Reproductive strategy & $\begin{array}{l}\text { Nest builder (social or solitary) } \\
\text { Cleptoparasitic }\end{array}$ & $\begin{array}{l}\text { Nest builder species construct their own nest and } \\
\text { are non-parasitic. } \\
\text { Cleptoparasitic bees enter the nest of their host bee } \\
\text { species, lay eggs and then leave the nest. }\end{array}$ \\
\hline Sociality & $\begin{array}{l}\text { Social } \\
\text { Solitary }\end{array}$ & $\begin{array}{l}\text { Social species included eusocial } \\
\text { as well as semi-social species (sensu Michener 2007). } \\
\text { Others were considered solitary. }\end{array}$ \\
\hline Nest location & $\begin{array}{l}\text { Below ground } \\
\text { Above ground }\end{array}$ & $\begin{array}{l}\text { Below-ground species nest in the soil. } \\
\text { Above-ground species nest in various types of } \\
\text { above-ground cavities (e.g. in plant stems or wood). }\end{array}$ \\
\hline Trophic specialisation & $\begin{array}{l}\text { Specialist (oligolectic) } \\
\text { Specialist (oil-collecting) } \\
\text { Generalist }\end{array}$ & $\begin{array}{l}\text { Oligolectic taxa collect pollen on a single plant } \\
\text { family. } \\
\text { Oil-collecting species collect oil on specific plant } \\
\text { species. } \\
\text { Generalist taxa are polylectic (i.e. collecting pollen } \\
\text { from several plant families) and non-oil-collecting } \\
\text { species. }\end{array}$ \\
\hline
\end{tabular}

as this characteristic can also lead species to rely on a limited number of specific plant species (Renner and Schaefer 2010).

The subgenus $L$. (Dialictus), a species-rich group present in most parts of the world, includes very diverse life-history traits. Most species are non-parasitic, social, belowground nesting and polylectic. But the subgenus also comprises parasitic, solitary and/or above-ground and wood nesting species (Michener 2007; Gibbs 2011). Species from this group are also morphologically monotonous and difficult to identify (Michener 2007) and, in the case of our study area, the lack of an identification key made identification at the species level impossible. Therefore, except for the body size that we obtained from the examination of our specimens, we did not record traits for the specimens of this group. Moreover, we did not draw conclusions regarding the nest location of some Megachile taxa. Recent observations in Pampean agro-ecosystems suggested that $M$. (Pseudocentron) gomphrenae Holmberg could nest below ground (Torretta et al. 2010), but we do not know if it exclusively uses below-ground nests. Megachile (Pseudocentron) gomphrenoides Vachal has been proven to nest above ground in plant stems (Torretta et al. 2012). For other Megachile taxa, we could not draw conclusions and nest location was specified as unknown.

\section{Data analyses}

We first considered separately the three sampling sessions in order to describe the temporal variation in the composition of bee assemblages (Figure 4). For subsequent analyses, we pooled the data over the three sessions. We then described the functional composition of assemblages in calculating the proportion of taxa for each life-history trait category (Figure 5). Given both the high dominance and the lack of information regarding the traits of the $L$. (Dialictus) individuals, the functional analysis remained relatively limited. 


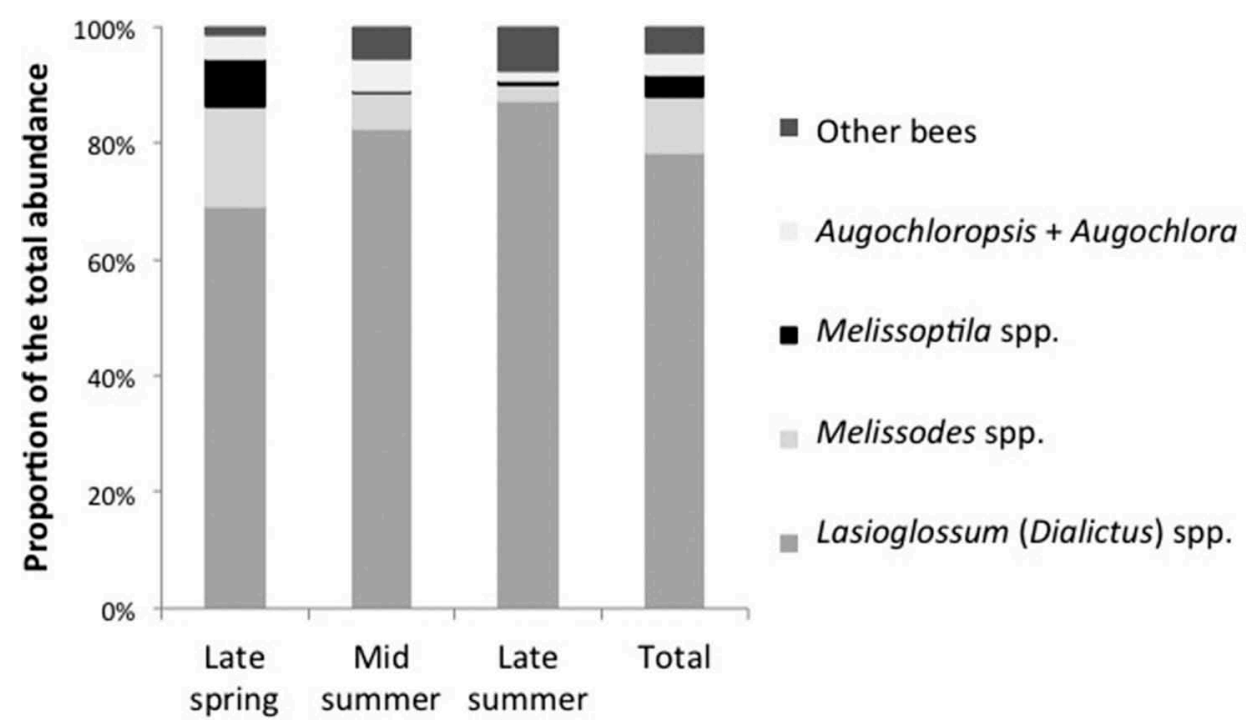

Figure 4. Percentage composition of main bee taxa captured during the three sampling rounds.

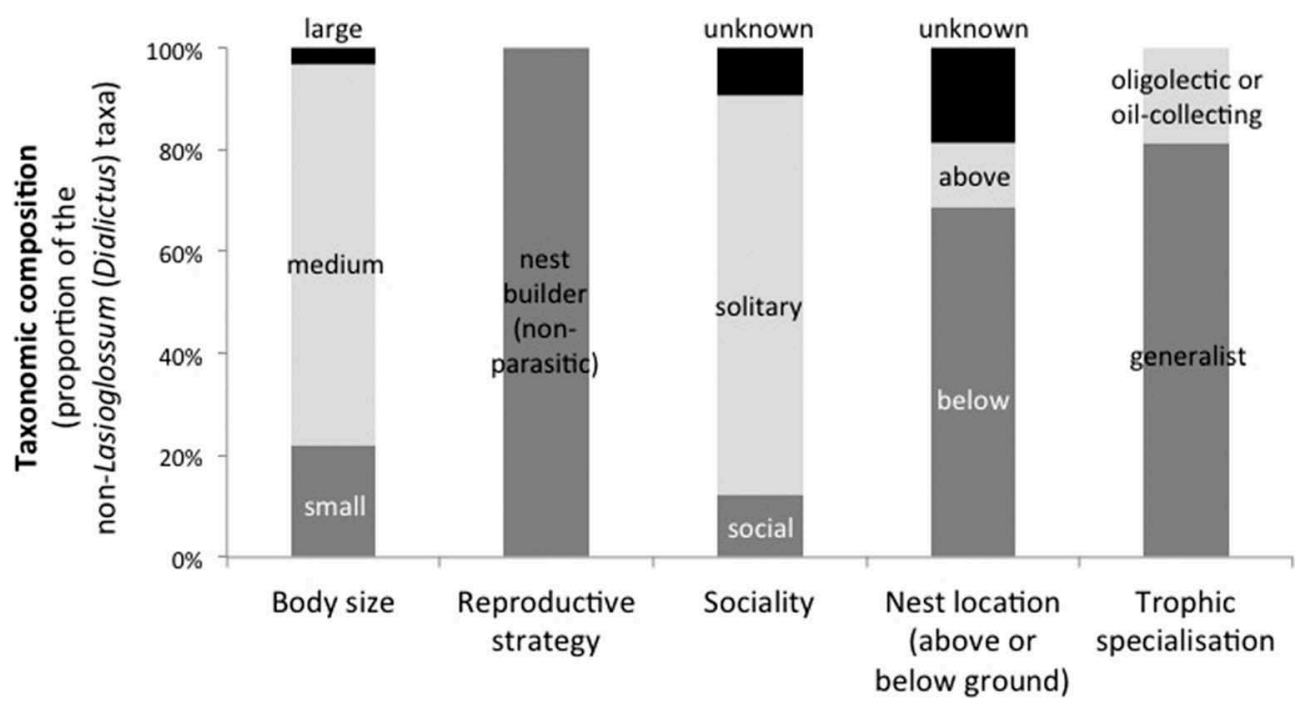

Figure 5. Functional composition of the non-Lasioglossum (Dialictus) bee assemblage: proportion of the taxa for each life-history trait category.

After preliminary Shapiro-Wilk tests indicating the non-normality of the variables, we used Wilcoxon rank sum tests to compare the two sets of sampling points (cropped vs. semi-natural areas) for (1) the overall bee abundance, (2) the number of $L$. (Dialictus) individuals, (3) the number of non-L. (Dialictus) individuals and (4) the number of bee taxa. Regarding ecological traits, we finally used Wilcoxon rank sum tests to compare the two sets of sampling points for (1) above-ground nesting bee individuals, (2) floral 
specialist bee individuals, and then, separately, (3) oligolectic and (4) oil-collecting bee individuals. Analyses were conducted using R software version 3.1.1 (R Core Team 2014).

\section{Results}

\section{Abundance and taxonomic composition}

Wild bee captures totalled 2384 individuals. Captures averaged 0.38 bees per trap per hour, which was calculated by only considering the period when bees were likely to fly (i.e. between 9 AM and 6 PM). A total of 33 taxa were identified at various levels (i.e. 28 species or morphospecies, one subgenus, three genera, and a group of two genera; Table 2), representing five families and 20 genera. The subgenus L. (Dialictus) was the most abundant taxon in all sampling sessions, accounting for $78 \%$ of total bee abundance, and ranging from $69 \%$ in late spring to $87 \%$ in late summer (Figure 4), but we could not assess species number and identity. Most taxa were represented by few individuals; there were 14 singletons (i.e. taxa represented by a single individual) and 12 taxa that comprised between two and 10 individuals (Table 2).

\section{Temporal variation in the composition of bee assemblages}

Bee abundance varied during the sampling season, with 964 individuals captured in late spring, 833 in mid-summer and 587 in late summer. Bee taxa exhibited different phenologies (Table 2). For instance, Melissoptila and Melissodes spp. (Apidae) were conspicuous spring species. Caenonomada bruneri Ashmead (Apidae) was more abundant in mid-summer, whereas Megachile spp. (Megachilidae) were more numerous in late summer. The abundance of Augochloropsis, Augochlora (Halictidae), and L. (Dialictus) spp. remained almost unchanged between late spring and mid-summer, but decreased in late summer.

\section{Life-history traits}

Due to the large dominance of the subgenus L. (Dialictus) and the lack of taxonomic and ecological knowledge regarding these specimens, the analysis of life-history traits at the assemblage level was rather limited. We present below the results regarding non- $L$. (Dialictus) bees.

Most taxa were non-parasitic, medium-sized, solitary bees which nest below ground, with generalist trophic behaviour (Table 2; Figure 5). However, there were four aboveground nesting species. Three species were oligolectic and three others were oil-collecting bees (Table 3). Both above-ground nesting species and floral specialist (oligolectic and oil-collecting) species had low abundance in our data set (total abundance less than or equal to six individuals). The oil-collecting bee Caenonomada bruneri was the exception, with 27 individuals captured, mostly in mid-summer. 


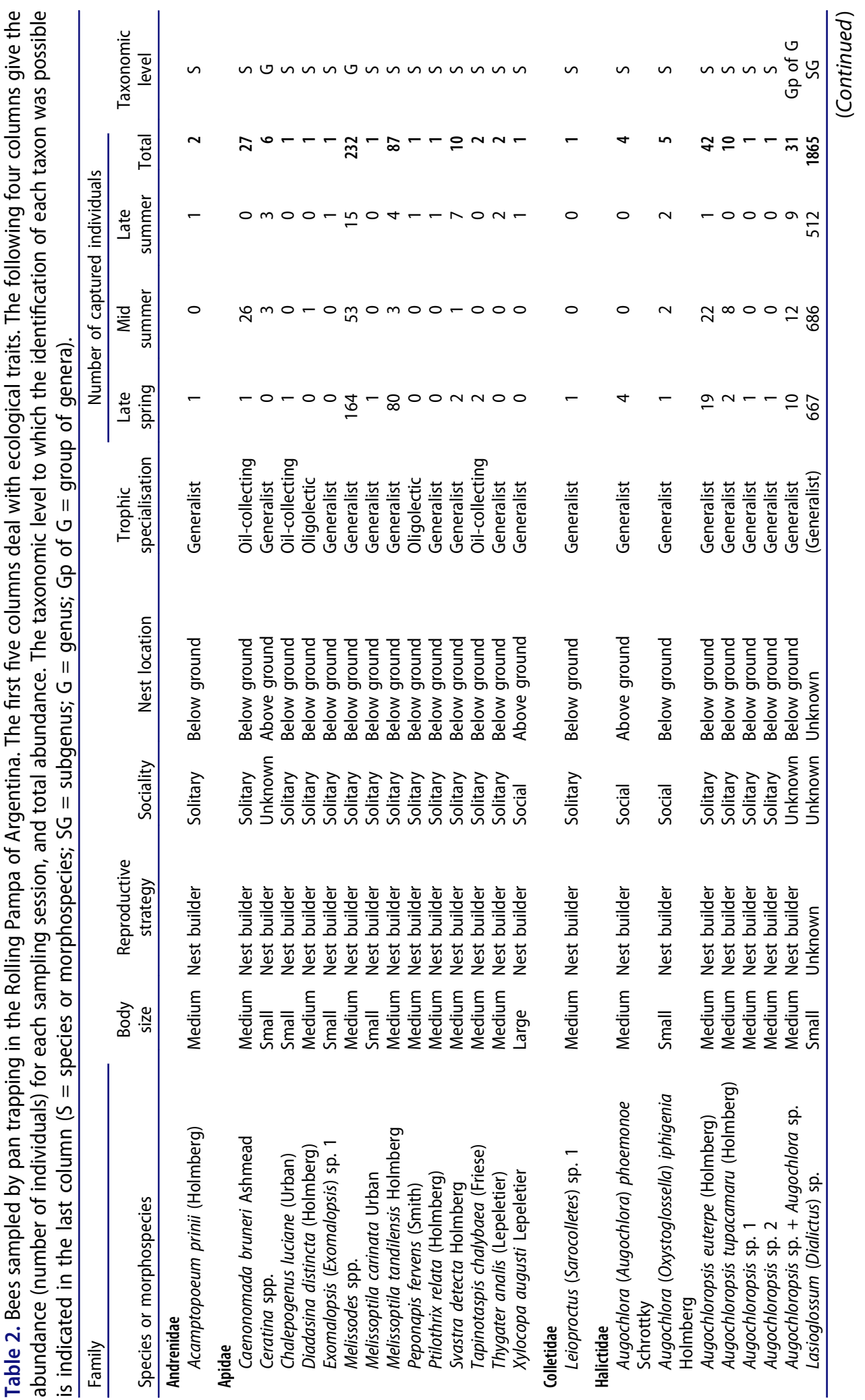




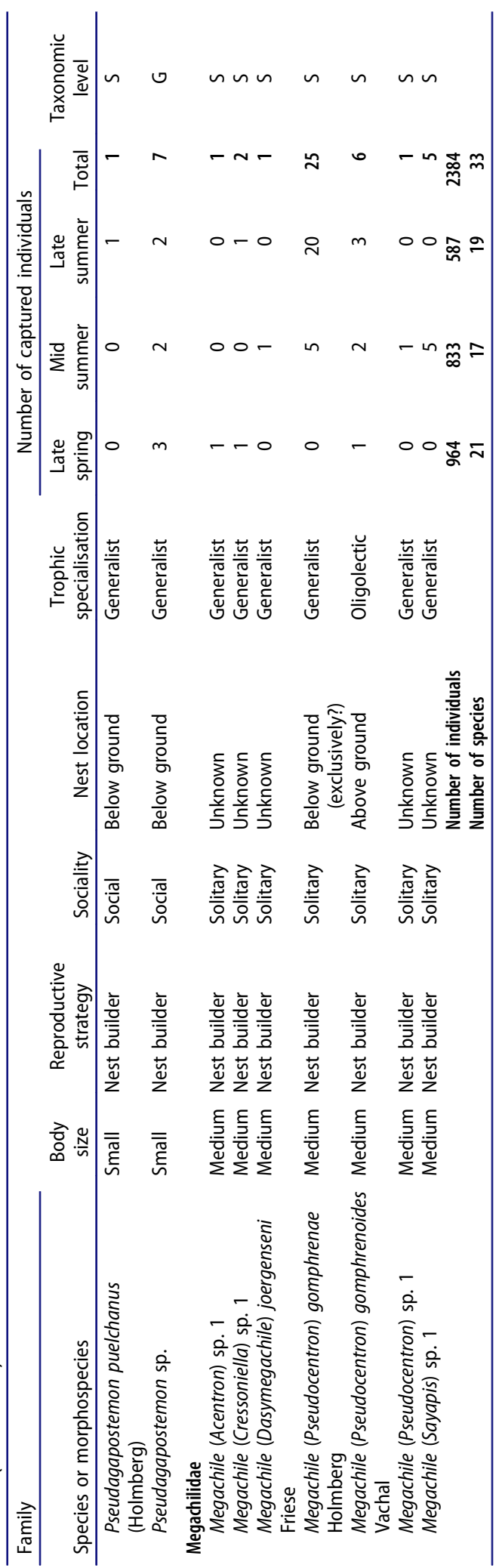




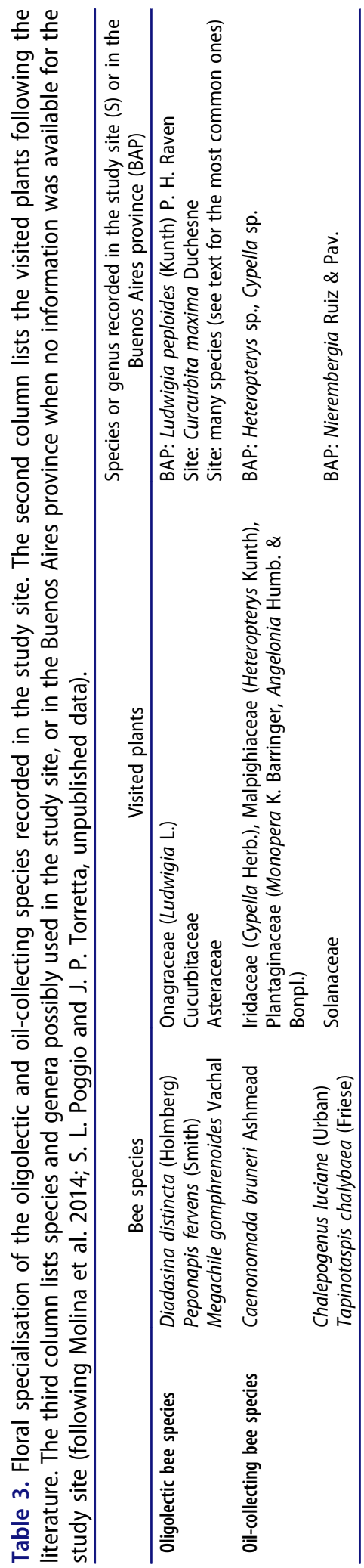




\section{Difference between cropped and semi-natural areas}

A total of 1545 individuals were collected in the cropped area (28 sampling points), while 839 individuals were collected in the semi-natural area (11 points). A total of 22 taxa were detected in the cropped area while 27 taxa were detected in the semi-natural area, despite lower sampling effort. Nine of the 14 singletons were found in the seminatural area. L. (Dialictus) individuals represented 85.3 and $65.2 \%$ of the total abundance in the cropped and in the semi-natural areas, respectively.

Neither the overall number of bee individuals (Figure 6a) nor the abundance of $L$. (Dialictus) individuals significantly differed between points located in the cropped area and points located in the semi-natural part of the study site (respectively $W=96.5$, $P=0.075$ and $W=140, P=0.673$ ). In contrast, the number of non- $L$. (Dialictus) individuals was on average three times higher in points of the semi-natural area than in points of the cropped area (mean $\pm \mathrm{SE}=26.5 \pm 6.2$ and $8.1 \pm 1.9$ respectively, $\mathrm{W}=31$, $P=0.0001$, Figure $6 \mathrm{~b}$ ). Similarly, the number of bee taxa was almost twice as much in the points of the semi-natural area as in the points of the cropped area (mean $\pm \mathrm{SE}=7.8 \pm 0.5$ and $4.3 \pm 0.4$ respectively, $\mathrm{W}=30.5, P=0.0001$, Figure $6 \mathrm{c}$ ).

The number of above-ground nesting individuals was four times higher in the seminatural area than in the cropped area (mean $\pm \mathrm{SE}=0.9 \pm 0.3$ and $0.2 \pm 0.1$ respectively, $\mathrm{W}=84.5, P=0.008$, Figure $7 \mathrm{a}$ ). The number of floral specialist individuals was seven times higher in the semi-natural area than in the cropped area (mean \pm SE $=2.5 \pm 1.0$ and $0.36 \pm 0.1$ respectively, $W=67, P=0.002$; Figure $7 \mathrm{~b}$ ). When we separated oligolectic species and oil-collecting species for a more detailed analysis, we found there was no difference for the number of oligolectic individuals ( $W=135.5, P=0.400$; Figure $7 c$ ), while the difference was high for the number of oil-collecting individuals $(W=70$, $P=0.001$, mean \pm SE $=2.3 \pm 1.0$ for semi-natural points and $0.2 \pm 0.1$ for the points in the cropped area; Figure 7d).

\section{Discussion}

Our research provides first insights about the taxonomic and functional composition of bee assemblages in the Rolling Pampa, which is one of the most intensively managed cropland areas in South America. We found that L. (Dialictus) individuals largely dominated the bee assemblages. Given knowledge of this group is incomplete, assessing species number and identity, as well as its functional composition, was beyond our possibilities. However, our study shows that some $L$. (Dialictus) species, a subgenus that typically comprises small-sized, generalist, ground-nesting and sometimes eusocial species, are apparently likely to fulfil their ecological requirements in cropped areas under no-tillage. On the contrary, more specialised (oil-collecting), above-ground nesting or larger species rely on semi-natural or less disturbed areas to perpetuate.

\section{Bee abundance}

The number of bees captured in a pan trap survey depends on regional and local factors that determine the actual bee abundance, as well as sampling characteristics such as trap colour, paint type (e.g. fluorescent, UV-reflecting) and number of traps, size or 

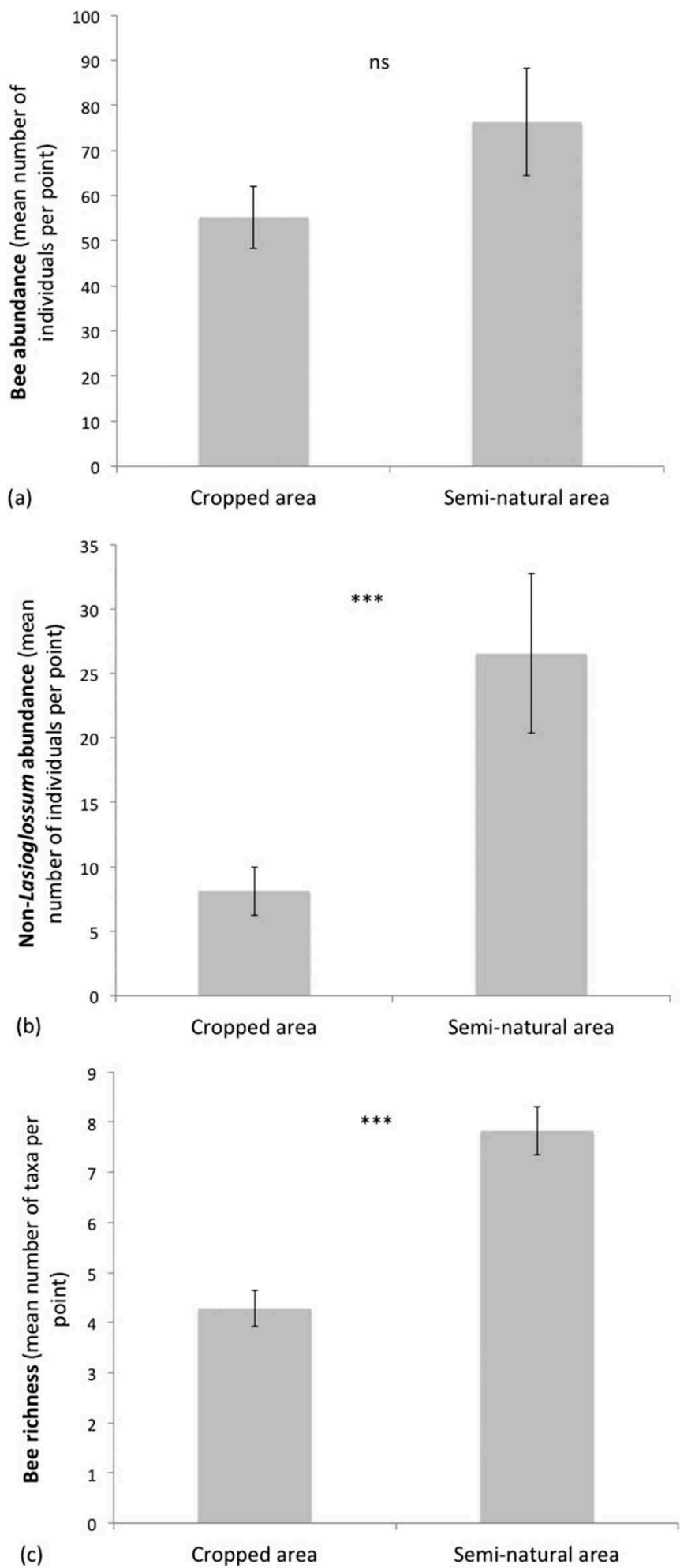

Figure 6. Mean number of (a) bee individuals, (b) non-Lasioglossum (Dialictus) bee individuals and (c) bee taxa per point, in cropped area ( $\mathrm{n}=28$ points) and semi-natural area ( $\mathrm{n}=11$ points). $\mathrm{ns}$ indicates a non-significant result. Asterisks indicate that means are significantly different (Wilcoxon rank sum test, $\left.{ }^{* * *}=P<0.001\right)$. Bars show SEs. 

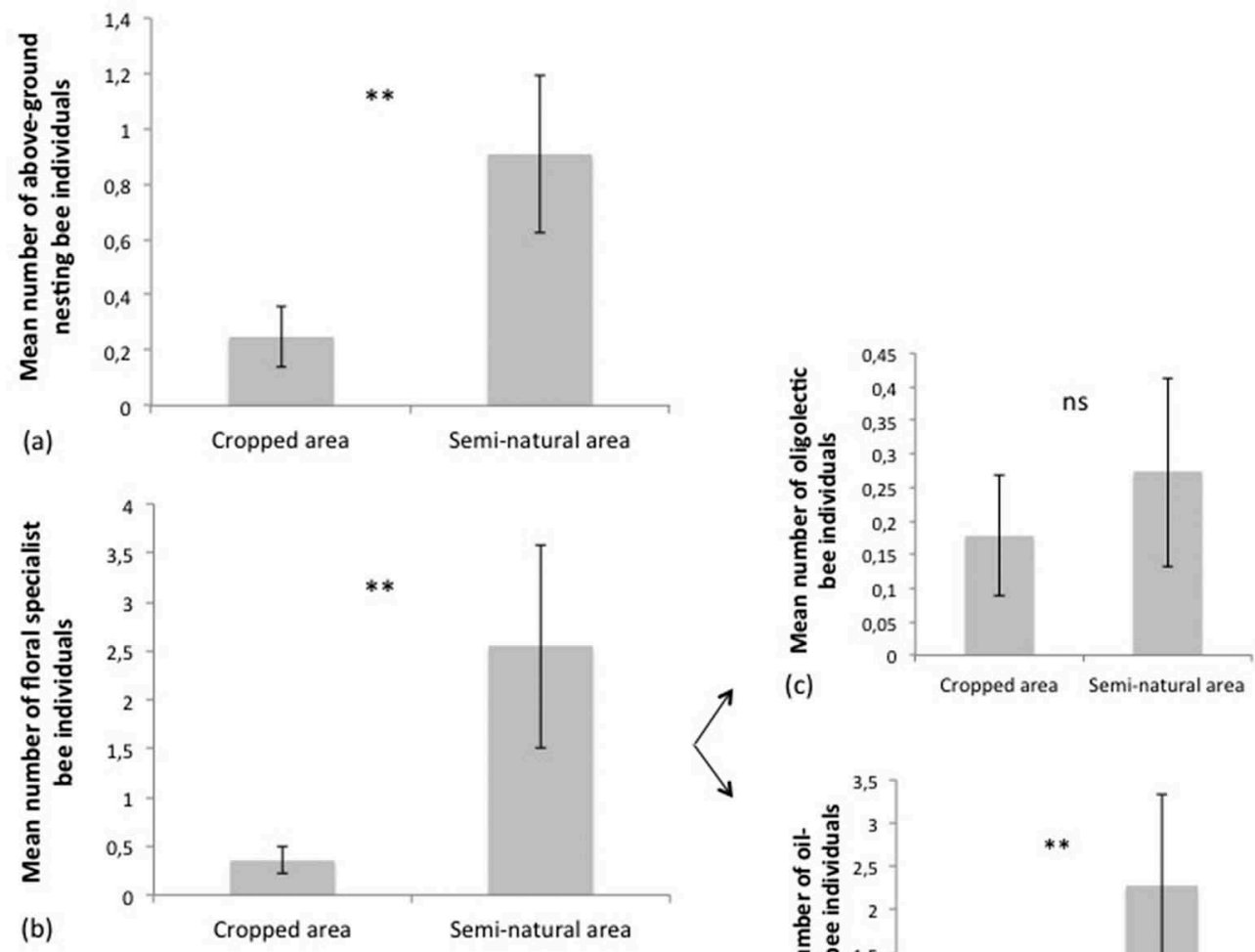

(d)

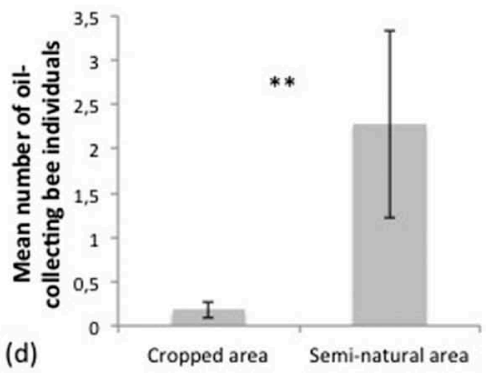

Figure 7. Mean number of (a) above-ground nesting bee individuals, (b) floral specialist bee individuals, (c) oligolectic bee individuals and (d) oil-collecting bee individuals in cropped area ( $n=28$ points) and semi-natural area ( $n=11$ points). $n s$ indicates a non-significant result. Asterisks indicate that means are significantly different (Wilcoxon rank sum test, ${ }^{* *}=P<0.01$ ). Bars show SEs.

position (e.g. Leong and Thorp 1999; Toler et al. 2005; Wilson et al. 2008; Droege et al. 2010; Grundel et al. 2011; Popic et al. 2013). Several studies have shown that pan trap attractiveness is higher when floral resources are scarce (Cane et al. 2000; Mayer and Kuhlmann 2004; Roulston et al. 2007; Wilson et al. 2008; Baum and Wallen 2011), which was the case in the field margins of our study site, particularly in the cropped area. Thus the sampling conditions of our study (pan traps placed in flower-poor field margins) could have promoted bee captures by pan traps and led to relatively high overall abundance (2384 individuals caught in three 48-hour sampling sessions conducted with 39 pan-trap triplets).

\section{Diversity and species composition}

Thirty-three taxa were identified (mainly species and morphospecies), most of them represented by very few individuals, which concurs with classical studies on bees (e.g. 
Williams et al. 2001; Sheffield et al. 2013a; Torné-Noguera et al. 2014). Our surveys detected all five bee families from the Neotropics (Michener 2007). Since many individuals, particularly from L. (Dialictus), could not be identified at the species level, species richness cannot be exactly assessed. Although the subgenus $L$. (Dialictus) remains to be revised in South America, it is estimated that the Pampas region might contain about 30 species (A. Roig Alsina, personal communication). Thus, total richness in our sampling ranged between 33 and about 60 species [for the highest estimation regarding L. (Dialictus) spp.]. In order to better assess $L$. (Dialictus) species richness and diversity, future studies could include DNA barcoding (see Magnacca and Brown 2012; Schmidt et al. 2015).

Lasioglossum spp. are known to be collected commonly in pan traps (Roulston et al. 2007; Westphal et al. 2008); hence, their dominance in our samples is not surprising. However, considering the assemblage diversity at the genus level, the level of dominance of this group (78\%) could be an indicator of a pauperised bee assemblage.

\section{Taxonomic and functional distribution of bees in the landscape}

Our findings suggest that the highly intensified cropland of the Rolling Pampa would provide suitable food resources and nesting sites for some L. (Dialictus) spp., thus enabling these species group to sustain relatively abundant populations. As explained above, knowledge is lacking regarding the taxonomic and functional composition of this subgenus in our data set. However, several reasons may explain the high abundance of L. (Dialictus) in our study.

First, some species in this group are eusocial, implying that when present, they occur in high abundance. Genetics could help to accurately assess the population status of the L. (Dialictus) species in our site, as in social species, high number of individuals does not necessarily mean high population size (i.e. number of reproductive units; see Woodard et al. 2015 for such issues in bumblebees).

Second, no-tillage, which is closely associated with growing HTGM soybean crops, may create favourable conditions for L. (Dialictus) individuals to nest in large areas (see Shuler et al. 2005 for a study where tillage was detrimental to below-ground nesting bees).

Third, these species are typically polylectic and, therefore, are able to feed on a wide array of plants. In particular, we can hypothesise that individuals of L. (Dialictus) spp. might obtain food resources in soybean fields. In comparison to 'mass-flowering crops', such as oilseed rape and sunflower, soybean is usually disregarded as an important food resource for bees, particularly because it is a self-compatible and self-pollinated plant, and its flowers are quite small and produce a low quantity of nectar (Erickson 1975). Nevertheless, it has been shown that different bee species do feed on soybean, both honeybee (Erickson 1975; Erickson et al. 1978; Chiari et al. 2005; Monasterolo et al. 2015) and wild bees (Rust et al. 1980; Yoshimura et al. 2006; Milfont et al. 2013; Gill and O'Neal 2015; Monasterolo et al. 2015). In Brazil, Milfont et al. (2013) collected three morphospecies of L. (Dialictus) on soybean flowers by netting. In the Chaco Serrano district of Argentina, Monasterolo et al. (2015) recorded visits on soybean flowers from four Halictidae species from the genera Augochlora, Augochloropsis and Lasioglossum (26, nine and 45 visit observations, respectively). Likewise, in the United States, Rust et al. (1980) sampled 29 species of wild bees on soybean flowers, being 16 species from Halictidae, mostly L. (Dialictus) spp. Moreover, L. (Dialictus) individuals were found 
carrying soybean pollen on their scopal hairs (Rust et al. 1980; Gill and O'Neal 2015). This observation not only provides evidence indicating that these species do visit soybean flowers, but also shows that their female individuals collect and carry pollen. Sowing soybean as double crops immediately after the harvest of cool-season crops is a usual practice in the Rolling Pampa. Consequently, soybean flowers may be available during most of the warm season (from late December to February, approximately), which may allow some bee taxa feeding on soybean flowers to access resources during a longer period.

In contrast to generalist $L$. (Dialictus) spp., the low abundance of other species may be explained by more specialised feeding or nesting behaviour. For example, Ceratina spp. (Apidae) and some Megachile spp. require specific micro-habitats to nest (i.e. stems of certain plant species or pre-existing cavities in dead wood, respectively). Oligolectic species collect pollen on a restricted number of plant species. Oil-collecting bees require visiting plants of particular botanical families. For these species, feeding or nesting requirements are not likely to be met in soybean fields and in the flower-poor margins prevailing in the study area. They may be strongly affected by the inhospitable conditions prevailing in intensively managed croplands. Our results show that many bee species strongly rely on the semi-natural grassland areas to perpetuate. Grasslands are still present in the farm where we worked, whereas they have disappeared from many farms of the Rolling Pampa, leading to situations with even less abundant and diverse habitats for bees. This was particularly the case for oil-collecting species, as they were on average 12 times more numerous in the points located in the semi-natural area than in the points located in the cropped area. Oligolectic species showed no affinity to the semi-natural area, probably because the most abundant one, Megachile gomphrenoides, is oligolectic on Asteraceae, which is a very large group that comprises many weed species (see the Materials and methods section). The crucial importance of semi-natural habitats to sustain bee diversity in agricultural landscapes has been observed in many studies all over the world (see Ricketts et al. 2008; Winfree et al. 2009; 2011; Garibaldi et al. $2011 \mathrm{~b}$ for reviews).

Overall, the bee assemblage in our study site has several characteristics suggesting an assemblage undergoing a severe level of disturbance. First, no cleptoparasitic bees were found [at least among the 519 non-L. (Dialictus) individuals] in spite of the relatively high number of captured individuals, and even if these bees are well caught by traps (Westphal et al. 2008). This group has recently been proposed as an indicator taxon to assess the status of a bee assemblage: the more abundant and diverse cleptoparasitic bees are, the more diverse and stable the bee assemblage is (Sheffield et al. 2013b). Second, above-ground nesting or oligolectic species, all presenting low relative abundances in our data set, have been shown to be more sensitive to disturbance (Moretti et al. 2009; Williams et al. 2010; Rader et al. 2014). We do not comment further on the quasi-absence of large species (one individual of the genus Xylocopa) as these species are known to be poorly caught by pan traps (Westphal et al. 2008).

\section{Conclusions}

This study provides first insights about the composition of bee assemblages in the Rolling Pampa, which is among the major HTGM soybean growing areas in the world. 
The relatively high abundance of the subgenus $L$. (Dialictus) indicates that some species in this group are likely to reach their ecological requirements in cropped areas under continuous no-tillage management. By contrast, we showed that semi-natural areas harboured a significantly higher number of bee taxa, and a larger number of individuals from the non-L. (Dialictus) taxa. Semi-natural remnants in the Rolling Pampa play a crucial role for sustaining bee diversity, from both taxonomic and functional points of view. Further field observations and improvements in taxonomic knowledge, particularly regarding the genus Lasioglossum, are needed to more accurately assess the diversity and abundance of wild bee assemblages in such intensive and homogeneous farming conditions. This is particularly needed in semi-natural habitats that are undergoing alterations, or even removal, due to agricultural intensification, such as woodlots, grasslands and specially field margins. We expect that high taxonomic and functional diversity of bees will be more concentrated in favourable semi-natural habitats, while their abundance will be diluted within crop fields, as a result of a spillover effect (Blitzer et al. 2012). Testing this hypothesis would have practical implications for restoring farmland mosaics to sustain bee assemblages comprising diverse life-history traits, which would ensure the provisioning of pollination service in the long term.

\section{Acknowledgements}

We greatly thank Arturo Roig Alsina (Museo Argentino de Ciencias Naturales, 'Bernardino Rivadavia', Buenos Aires, Argentina) for his help with bee identification, Luciana D'Acunto and Alain Butet for assistance in field work, Gonzalo García and Clémence Vannier for Geographic information system support, and the Ortíz Basualdo family, owners of Estancia 'Las Polvaredas', for their consent to carry out this research on their farm and for logistic assistance. We also warmly thank Bernard Vaissière for providing useful bibliographical references, and Benoit Geslin and Arnaud Le Nevé for fruitful discussions. We are grateful to two anonymous referees for their constructive comments. VLF was supported by a post-doctoral fellowship of the French-Argentine 'Bernardo Houssay' programme. The cooperation between the French and Argentine research groups has been supported by the research cooperation programme between ECOS Sud (France) and the Ministry of Science and Technological Innovation of Argentina (project ECOS-MINCyT 2007, A07B04). This research was also supported by ANPyCT-MINCyT (project PICT 2007-00491).

\section{Disclosure statement}

No potential conflict of interest was reported by the authors.

\section{References}

Aguiar AJC, Melo GAR. 2009. Notes on oil sources for the bee genus Caenonomada (Hymenoptera, Apidae, Tapinotaspidini). Rev Bras Entomol. 53:154-156.

Archer CR, Pirk CWW, Carvalheiro LG, Nicolson SW. 2014. Economic and ecological implications of geographic bias in pollinator ecology in the light of pollinator declines. Oikos. 123:401-407.

Baudry J, Poggio SL, Burel F, Laurent C. 2010. Agricultural landscape changes through globalization and biodiversity effects. In: Primdahl J, Swaffield S, editors. Globalisation and agricultural landscapes: change patterns and policy trends in developed countries. Cambridge, UK: Cambridge University Press; p. 57-72. 
Baum KA, Wallen KE. 2011. Potential bias in pan trapping as a function of floral abundance. J Kans Entomol Soc. 84:155-159.

Biesmeijer JC, Roberts SPM, Reemer M, Ohlemüller R, Edwards M, Peeters T, Schaffers AP, Potts SG, Kleukers R, Thomas CD, et al. 2006. Parallel declines in pollinators and insect-pollinated plants in Britain and the Netherlands. Science. 313:351-354.

Blitzer EJ, Dormann CF, Holzschuh A, Klein AM, Rand TA, Tscharntke T. 2012. Spillover of functionally important organisms between managed and natural habitats. Agric Ecosyst Environ. 146:34-43.

Brown MJF, Paxton RJ. 2009. The conservation of bees: a global perspective. Apidologie. 40:410-416.

Burgos JJ, Vidal AL. 1951. Los climas de la República Argentina según la nueva clasificación de Thornthwaite. Meteoros. 1:3-32.

Cane JH, Minckley RL, Kervin LJ. 2000. Sampling bees (Hymenoptera: apiformes) for pollinator community studies: pitfalls of pan-trapping. J Kans Entomol Soc. 73:225-231.

Chacoff NP, Morales CL, Garibaldi LA, Ashworth L, Aizen MA. 2010. Pollinator dependence of Argentinean agriculture: current status and temporal analysis. Americas J Plant Sci Biotech. 3:106-116.

Chiari WC, Toledo VAA, Ruvolo-Takasusuki MCC, Attencia VM, Costa FM, Kotaka CS, Sakaguchi ES, Magalhaes HR. 2005. Floral biology and behavior of Africanized honeybees Apis mellifera in soybean (Glycine max L. Merril). Braz Arch Biol Technol. 48:367-378.

Cocucci AA, Sérsic A, Roig Alsina A. 2000. Oil-collecting structures in Tapinotaspidini: their diversity. Function and probable origin. Mitteilungen der Münchner Entomologischen Gesellschaft. 90:51-74.

Dalmazzo M, Roig-Alsina A. 2012. Nest structure and notes on the social behavior of Augochlora amphitrite (Schrottky) (Hymenoptera, Halictidae). J Hym Res. 26:17-29.

Dalmazzo M, Roig-Alsina A. 2015. Social biology of Augochlora (Augochlora) phoemonoe (Hymenoptera, Halictidae) reared in laboratory nests. Insectes Soc. doi:10.1007/s00040-015-0412-8

DPEBA, 2011. Dirección Provincial de Estadística, Ministerio de Economía, Provincia de Buenos Aires, Argentina. http://www.ec.gba.gov.ar/Estadistica/index.htm [cited 2015 Apr 12].

Droege S, Tepedino VJ, Lebuhn G, Link W, Minckley RL, Chen Q, Conrad C. 2010. Spatial patterns of bee captures in North American bowl trapping surveys. Insect Cons Divers. 3:15-23.

Erickson EH. 1975. Variability of floral characteristics influence honey bee visitation to soybean blossoms. Crop Sci. 15:767-771.

Erickson EH, Berger GA, Shannon JG, Robins JM. 1978. Honey bee pollination increases soybean yields in the Mississippi delta region of Arkansas and Missouri. J Econ Entomol. 71:601-603.

Freitas BM, Imperatriz-Fonseca VL, Medina LM, Kleinert AMP, Galetto L, Nates-Parra G, QuezadaEuán JJG. 2009. Diversity, threats and conservation of native bees in the Neotropics. Apidologie. 40:332-346.

Garibaldi LA, Muchhala N, Motzke I, Bravo-Monroy L, Olschewski R, Klein AM. 2011a. Services from plant-pollinator interactions in the Neotropics. In: Rapidel B, DeClerck F, Le Coq JF, Beer J, editors. Ecosystem services from agriculture and agroforestry: measurement and payment. London, UK: Earthscan; p. 119-139.

Garibaldi LA, Steffan-Dewenter I, Kremen C, Morales JM, Bommarco R, Cunningham SA, Carvalheiro LG, Chacoff NP, Dudenhöffer JH, Greenleaf SS, et al. 2011b. Stability of pollination services decreases with isolation from natural areas despite honey bee visits. Ecol Lett. 14:1062-1072.

Gibbs J. 2011. Revision of the metallic Lasioglossum (Dialictus) of eastern North America (Hymenoptera: Halictidae: Halictini). Zootaxa. 3073:1-216.

Gill KA, O'Neal ME. 2015. Survey of soybean insect pollinators: community identification and sampling method analysis. Environ. Entomol. 44:488-498.

Goulson D, Nicholls E, Botias C, Rotheray EL. 2015. Combined stress from parasites pesticides and lack of flowers drives bee declines. Science. 347:6229.

Grundel R, Frohnapple KJ, Jean RP, Pavlovic NB. 2011. Effectiveness of bowl trapping and netting for inventory of a bee community. Environ Entomol. 40:374-380. 
Hall AJ, Rebella CM, Ghersa CM, Culot JP. 1992. Field-crop systems of the Pampas. In: Pearson CJ, editor. Ecosystems of the world: field crop ecosystems. Amsterdam: Elsevier; p. 413-450.

Kremen C, M'Gonigle LK. 2015. Small-scale restoration in intensive agricultural landscapes supports more specialized and less mobile pollinator species. J Appl Ecol. 52:602-610.

Leong JM, Thorp RW. 1999. Colour-coded sampling: the pan trap colour preferences of oligolectic and nonoligolectic bees associated with a vernal pool plant. Ecol Entomol. 24:329-335.

Magnacca KN, Brown MJF. 2012. DNA barcoding a regional fauna: Irish solitary bees. Mol Ecol Resour. 12:990-998.

Marrero HJ, Torretta JP, Medan D. 2014. Effect of land use intensification on specialization in plantfloral visitor interaction networks in the Pampas of Argentina. Agric Ecosyst Environ. 188:63-71.

Martins RP, Borges JC. 1999. Use of Ludwigia (Onagraceae) pollen by a specialist bee, Diadasina distincta (Hymenoptera: Apidae), at a nesting site in southeastern Brazil. Biotropica. 31:530-534.

Mayer C, Kuhlmann M. 2004. Synchrony of pollinators and plants in the winter rainfall area of South Africa-observations from a drought year. Trans Roy Soc South Afr. 59:55-57.

Medan D, Torretta JP, Hodara K, De La Fuente EB, Montaldo N. 2011. Effects of agriculture expansion and intensification on the vertebrate and invertebrate diversity in the Pampas of Argentina. Biodivers Conserv. 20:3077-3100.

Michener CD. 2007. The bees of the world. 2nd ed. Baltimore (MD): The Johns Hopkins University Press.

Milfont MO, Rocha EEM, Lima AON, Freitas BM. 2013. Higher soybean production using honeybee and wild pollinators, a sustainable alternative to pesticides and autopollination. Environ Chem Lett. 11:335-341.

Molina GAR, Poggio SL, Ghersa CM. 2014. Epigeal arthropod communities in intensively farmed landscapes: effects of land use mosaics, neighbourhood heterogeneity, and field position. Agric Ecosyst Environ. 192:135-143.

Monasterolo M, Musicante ML, Valladares GR, Salvo A. 2015. Soybean crops may benefit from forest pollinators. Agric Ecosyst Environ. 202:217-222.

Moretti M, De Bello F, Roberts SPM, Potts SG. 2009. Taxonomical vs. functional responses of bee communities to fire in two contrasting climatic regions. J Anim Ecol. 78:98-108.

Poggio SL, Chaneton EJ, Ghersa CM. 2010. Landscape complexity differentially affects alpha, beta, and gamma diversities of plants occurring in fencerows and crop fields. Biol Conserv. 143:24772486.

Poggio SL, Chaneton EJ, Ghersa CM. 2013. The arable plant diversity of intensively managed farmland: effects of field position and crop type at local and landscape scales. Agric Ecosyst Environ. 166:55-64.

Popic TJ, Davila YC, Wardle GM. 2013. Evaluation of common methods for sampling invertebrate pollinator assemblages: net sampling out-perform pan traps. PLoS ONE. 8:e66665.

Potts SG, Biesmeijer JC, Kremen C, Neumann P, Schweiger O, Kunin W. 2010. Global pollinator declines: trends, impacts and drivers. Trends Ecol Evol. 25:345-353.

R Core Team. 2014. R: A language and environment for statistical computing. R Foundation for Statistical Computing, Vienna, Austria. Available from: http://www.R-project.org/

Rader R, Bartomeus I, Tylianakis JM, Laliberté E. 2014. The winners and losers of land use intensification: pollinator community disassembly is non-random and alters functional diversity. Diversity Distrib. 20:908-917.

Renner SS, Schaefer H. 2010. The evolution and loss of oil-offering flowers: new insights from dated phylogenies for angiosperms and bees. Philos Trans R Soc Lond B Biol Sci. 365:423-435.

Requier F, Odoux JF, Tamic T, Moreau N, Henry M, Decourtye A, Bretagnolle V. 2015. Honey-bee diet in intensive farmland habitats reveals an unexpectedly high flower richness and a critical role of weeds. Ecol Appl. 25:881-890.

Ricketts TH, Regetz J, Steffan-Dewenter I, Cunningham SA, Kremen C, Bogdanski A, GemmillHerren B, Greenleaf SS, Klein AM, Mayfield MM, et al. 2008. Landscape effects on crop pollination services: are there general patterns? Ecol Lett. 11:499-515. 
Roulston TH, Smith SA, Brewster AL. 2007. A comparison of pan trap and intensive net sampling techniques for documenting a bee (Hymenoptera: Apiformes) fauna. J Kans Entomol Soc. 80:179-181.

Rust RW, Macon CE, Erickson EH. 1980. Wild bees on soybeans, Glycine max. Environ Entomol. 9:230-232.

Sáez A, Sabatino M, Aizen MA. 2012. Interactive effects of large- and small-scale sources of feral honey-bees for sunflower in the Argentine Pampas. PLoS ONE. 7:e30968.

Schmidt S, Schmid-Egger C, Morinière J, Haszprunar G, Hebert PDN. 2015. DNA barcoding largely supports 250 years of classical taxonomy: identifications for Central European bees (Hymenoptera, Apoidea partim). Mol Ecol Resour. 15:985-1000.

Sheffield CS, Kevan PG, Pindar A, Packer L. 2013a. Bee (Hymenoptera: Apoidea) diversity within apple orchards and old fields in the Annapolis Valley, Nova Scotia, Canada. Can Entomol. 145:94-114.

Sheffield CS, Kevan PG, Westby SM, Smith RF. 2008. Diversity of cavity-nesting bees (Hymenoptera: Apoidea) within apple orchards and wild habitats in the Annapolis Valley, Nova Scotia, Canada. Can Entomol. 140:235-249.

Sheffield CS, Pindar A, Packer L, Kevan PG. 2013b. The potential of cleptoparasitic bees as indicator taxa for assessing bee communities. Apidologie. 44:501-510.

Shuler RE, Roulston TH, Farris GE. 2005. Farming practices influence wild pollinator populations on squash and pumpkin. J Econ Entomol. 98:790-795.

Soriano A. 1991. Río de la Plata grasslands. In: Coupland RT, editor. Ecosystems of the world 8. Natural grasslands. Amsterdam: Elsevier; p. 367-407.

Steffan-Dewenter I, Potts SG, Packer L. 2005. Pollinator diversity and crop pollination services are at risk. Trends Ecol Evol. 20:651-652.

Toler TR, Evans EW, Tepedino VJ. 2005. Pan-trapping for bees (Hymenoptera: Apiformes) in Utah's west desert: the importance of color diversity. Pan-Pacific Entomol. 81:103-113.

Torné-Noguera A, Rodrigo A, Arnan X, Osorio S, Barril-Graells H, Correia Da Rocha-Filho L, Bosch J. 2014. Determinants of spatial distribution in a bee community: nesting resources, flower resources, and body size. PLoS ONE. 9:e97255.

Torretta JP, Durante SP, Colombo MG, Basilio AM. 2012. Nesting biology of the leafcutting bee Megachile (Pseudocentron) gomphrenoides Vachal (Hymenoptera: Megachilidae) in an agroecosystem. Apidologie. 43:624-633.

Torretta JP, Medan D, Roig Alsina A, Montaldo NH. 2010. Visitantes florales diurnos del girasol (Helianthus annuus, Asterales: Asteraceae) en la Argentina [Diurnal sunflower floral-visitors (Helianthus annuus, Asterales: Asteraceae) in Argentina]. Rev Soc Entomol Argent. 69:17-32. Spanish.

Torretta JP, Poggio SL. 2013. Species diversity of entomophilous plants and flower-visiting insects is sustained in the field margins of sunflower crops. J Nat Hist. 47:139-165.

Vanbergen AJ, The Insect Pollinators Initiative. 2013. Threats to an ecosystem service: pressures on pollinators. Front Ecol Environ. 11:251-259.

Westphal C, Bommarco R, Carré G, Lamborn E, Morison N, Petanidou T, Potts SG, Roberts SPM, Szentgyörgyi H, Tscheulin T, et al. 2008. Measuring bee diversity in different European habitats and biogeographical regions. Ecol Monogr. 78:653-671.

Westphal C, Steffan-Dewenter I, Tscharntke T. 2003. Mass flowering crops enhance pollinator densities at a landscape scale. Ecol Lett. 6:961-965.

Westrich P. 1996. Habitat requirements of central European bees and the problems of partial habitats. In: Matheson A, Buchmann SL, O'Toole C, Westrich P, Williams IH, editors. The Conservation of Bees. London, UK: Academic Press; p. 1-16.

Williams NM, Crone EE, Roulston TH, Minckley RL, Packer L, Potts SG. 2010. Ecological and lifehistory traits predict bee species responses to environmental disturbances. Biol Conserv. 143:2280-2291. 
Williams NM, Minckley RL, Silveira FA. 2001. Variation in native bee faunas and its implications for detecting community change. Conserv Ecol. 5:57-89.

Wilson JS, Griswold T, Messinger OJ. 2008. Sampling bee communities (Hymenoptera: Apiformes) in a desert landscape: are pan traps sufficient? J Kans Entomol Soc. 81:288-300.

Winfree R, Aguilar R, Vázquez DP, Lebuhn G, Aizen MA. 2009. A meta-analysis of bees' responses to anthropogenic disturbance. Ecology. 90:2068-2076.

Winfree R, Bartomeus I, Cariveau DP. 2011. Native pollinators in anthropogenic habitats. Annu Rev Ecol Evol Syst. 42:1-22.

Woodard SH, Lozier JD, Goulson D, Williams PH, Strange JP, Jha S. 2015. Molecular tools and bumble bees: revealing hidden details of ecology and evolution in a model system. Mol Ecol. 24:2916-2936.

Yoshimura Y, Matsuo K, Yasuda K. 2006. Gene flow from GM glyphosate-tolerant to conventional soybeans under field conditions in Japan. Environ Biosafety Res. 5:169-173. 